\title{
METABOLISM AND REPRODUCTIVE FUNCTION DURING THE POSTPARTUM PERIOD IN FIRST-CALF COWS WHEN INTRODUCING THE PLACENTA EXTRACT
}

\section{O.S. MITYASHOVA, I.V. GUSEV, I.Yu. LEBEDEVA}

\author{
L.K. Ernst All-Russian Research Institute of Animal Husbandry, Federal Agency of Scientific Organizations, 60, pos. \\ Dubrovitsy, Podolsk District, Moscow Province, 142132 Russia, e-mail irledv@mail.ru \\ ORCID: \\ Mityashova O.S. orcid.org/ 0000-0002-0401-5088 \\ Lebedeva I.Yu. orcid.org/ 0000-0002-7815-7900
}

Gusev I.V. orcid.org/ 0000-0002-2346-4313

The authors declare no conflict of interests

Acknowledgements:

Supported financially by Federal Agency of Scientific Organizations

Received December 30, 2016

\begin{abstract}
Most reproductive disorders in dairy cows are associated with postpartum metabolic state. One approach to normalizing the reproductive function is to use biostimulators, which have a modulating effect on the immune, metabolic, and endocrine systems. The aim of the present research was to study the action of the cattle placenta extract on the metabolic adaptation and reproductive system functioning during the postpartum period in first-calf cows. We have conducted for the first time monitoring of indicators of metabolism and the steroidogenic ovarian activity in first-calf cows, treated with the placenta extract, during the transition period and two months after calving and also assessed the reproduction indices. The raw material for the preparation was placenta separated within 4-6 hours after calving. The extract was isolated from placenta according to the procedure, described earlier (M.V. Varenikov et al., 2010), with the use of some modifications. Effects of the extract were evaluated in first-calf cows of the Black Pied breed (Bos taurus taurus) on the basis of ZAO PZ «Barybino» (Domodedovo Region, Moscow Province) in 2015-2016. Seven to fourteen days prior to calving and on the day of calving, cows of the group I (control, $n=8$ ) received the saline, and cows of the group II (experiment, $n=11$ ) received $20 \mathrm{ml}$ of the placenta extract. Before the treatment and on days 3 to 5,20 to 25 and 50 to 60 after calving, the animal blood was taken for biochemical analysis and enzyme immunoassay. In serum samples, the concentration of total protein and its fractions, urea, bilirubin, cholesterol, calcium, and phosphorus, the activity of aspartate aminotransferase (AST, EC 2.6.1.1) and alanine aminotransferase (ALT, EC 2.6.1.2), and the content of progesterone and estradiol-17 $\beta$ were measured. Twelve months after calving, based on the analysis of zootechnical and pedigree records, the reproduction indices (the pregnancy rate, calving to conception interval, and service per conception rate) and the 305-day milk yield were determined. A rise $(\mathrm{p}<0,001)$ in the blood content of total protein (by $24.9 \%$ ) and its globulin fraction (by $51.8 \%$ ) was observed on days 20 to 25 after calving only in animals of the group II. The cholesterol concentration in the blood of these cows remained unchanged, whereas it was reduced by $33 \%(\mathrm{p}<0.05)$ in control cows from days 3-5 to days 20-25 after calving. During the studied period, an increase in the serum activity of ALT was more pronounced in cows of the group II, while a raise in the activity of AST was considerable only in control animals. On days 20-25, the progesterone concentration in the blood of experimental cows was $57.7 \%$ lower than in the control group $(p<0.05)$. However, 50-60 days after calving, the level of blood progesterone in experimental animals rose sharply and was four times higher than in control ones $(\mathrm{p}<0.01)$. The treatment of cows also resulted in a reduction in the calving to conception interval from $123.5 \pm 10.5$ to $95.1 \pm 5.8$ days $(\mathrm{p}<0.05)$. Thus, the injection of the cattle placenta extract to first-calf cows exerts modulating effects on metabolism, primarily lipid metabolism, as well enhances the luteal activity of ovaries during the postpartum period. Normalization of the metabolic and hormonal status of cows is, obviously, related to a rise in the reproductive ability of the animals and leads to a reduction in the subsequent calving to conception interval.
\end{abstract} ductive ability

Keywords: first-calf cows, placenta extract, metabolism, ovarian steroid hormones, repro-

Low reproduction of the herd is one of the main problems of modern dairy cattle breeding both in Russia and abroad [1,2]. Reduced reproductive 
ability of dairy cows is due to prolonged postpartum anestrus, ovarian dysfunction, low fertility, high embryonic mortality, increased incidence of infectious diseases of the uterus because of weakened immunity and other disorders $[1,3]$. As a consequence, up to $20 \%$ of farm cows are subjected to culling already in the first lactation, and the calving interval is more than 400 days [4, 5].

The disorders in highly productive dairy cows are mostly associated with the metabolic state after calving [1, 6, 7]. In the early postpartum period, the animals lack the nutrients to maintain lactation. This leads to a negative energy balance which is compensated by mobilizing animal's own resources. In this, due to the limited supply of glucose, the main source of energy is fat depots [8]. The catabolic nature of metabolism during early lactation leads to a change in blood metabolites and metabolic hormones which affect animal fertility $[1,7,9]$. In addition, redirection of the main metabolic pathways for lactation causes a lack of energy and plastic resources to maintain other functions, primarily reproductive. The first-calf cows are in the most difficult situation, as their growth still requires additional resources [10].

To accelerate the restoration of the reproductive function of cows after calving, hormone preparations are widely practiced $[11,12]$. An alternative approach is biostimulants with a modulating effect on the immune, metabolic and endocrine systems [13-15]. Such biostimulants can be extracts or tissue preparations of the placenta, which have a therapeutic and preventive effect on inflammation, oxidative and degenerative processes, resorption of exudates and scars, endocrine disorders, growth [16-20]. A homologous extract of the placenta injected before and after lambing stimulates udder development and increases the milk yield in sheep [21]. Data have been obtained on the reduction in the number of post-calving complications and obstetric gynecological diseases in cows after the application of human placenta [22, 23]. In the All-Russian Research Institute of Animal Husbandry a positive effect of cattle placenta extract on reproductive health and the reproductive function of cows has been shown [24, 25]. It was found that the maximum reduction of the open days is achieved after the administration of the placenta extract to animals with a higher milk yield (over $5000 \mathrm{~kg}$ ), that is, with more pronounced postpartum metabolic disorders. These data suggest that the components of cattle placenta can normalize metabolism in cows post calving and thus modulate their reproductive ability.

In this work, we first studied the metabolism, steroidogenic activity of ovaries and reproduction indices in the first-calf cows after admiration of placenta extract during the transit period and 2 months after calving. placenta extract application led to a higher blood cholesterol level and a shorter open days compared to control animals. In addition, there was a marked increase in serum progesterone concentration 2 months after calving which indicates a faster recovery of the sexual cycle in cows with the placenta extract administered.

Our goal was to study the effect of cattle placenta extract on the metabolic adaptation and reproductive function during postpartum period in the firstcalf cows with a milk production of over $6000 \mathrm{~kg}$.

Technique. For extraction we used the afterbirth, separated within 4-6 hours after calving. A pure placenta without visible pathological changes in the tissues was collected from healthy black-and-white Holstein cows of the 2nd and 4th calving housed in OAO Rumyantsevskoye (Nizhny Novgorod region). The extract from the placenta was isolated according to the procedure described earlier [24] with modifications. After microwave exposure, the obtained extract was mixed with distilled water (1:3) and boiled in a microwave oven R-2471J (Sharp Corporation, Thailand) for $5 \mathrm{~min}$. After cooling, the resulting suspension was centrifuged for $20 \mathrm{~min}$ at $1000 \mathrm{~g}$ in a GR 412 centrifuge (Jouan, France), the 
supernatant was passed through a paper filter. For antibacterial treatment, $0.5 \%$ alcohol solution of phenol $(0.6 \%$ of the total volume $)$ was added to the filtrate, and the solution was filtered through a sterile filter with a pore size of $0.45 \mu \mathrm{m}$.

The cytotoxicity of the finished placenta extract was tested on infantile female laboratory Wistar rats. After subcutaneous injection of $0.5 \mathrm{ml}$ of the extract the rats was observed for 1 week.

The effect of the placenta extract on the metabolism and reproductive function of Black Pied first-calf cows (Bos taurus taurus) was investigated at ZAO PZ Barybino (Domodedovo Region, Moscow Province) in 2015-2016. Animals were kept in loafing yard. The ration corresponded to zootechnical norms. All experiments were carried out in accordance with the Helsinki Declaration (World Medical Association Declaration of Helsinki: ethical principles for medical research involving human subjects, 1964-2013) and the requirements of good laboratory practice (National Standard of the Russian Federation GOST R 53434-2009). One to two weeks before the proposed calving, according to the principle of analogues, 19 first-calf cows were selected, which were divided into two groups. The animals of group I (control, $n=8$ ) were treated with saline. Animals of group II (experiment, $n=11) 2$ times (7-14 days before the proposed calving and on the date of actual calving) were injected subcutaneously into the neck with $20 \mathrm{ml}$ of the placenta extract.

Blood was taken before (7-14 days prior to calving) and after the introduction of the extract (on days 3-5, 20-25 and 50-60 after the actual calving) from the tail vein with an Apexlab vacuum system (Hebei Xinle Sci \& Tech Co., Ltd, China). After receiving the serum, the samples were frozen and stored at $-20{ }^{\circ} \mathrm{C}$ for subsequent analyses of biochemical parameters and concentration of ovarian steroid hormones.

In blood serum, the concentration of the total protein and its fractions, urea, bilirubin, cholesterol, calcium, phosphorus, the aspartate aminotransferase (AST, EC 2.6.1.1) and alanine aminotransferase (ALT, EC 2.6.1.2) activity were assessed on a ChemWell automatic biochemical analyzer (Awareness Technology, USA) with reagents of Analyticon Biotechnology AG (Germany). The estradiol-17 $\beta$ and progesterone level in serum was determined in enzyme immunoassay test with a Uniplan (Picon, Russia) plate-type spectrophotometer and commercial kit of reagents (NVO Immunotech, Russia) according to the company's instructions. The sensitivity of the test was 30 pmol 1 for estradiol-17 $\beta$ and $0.4 \mathrm{nmol} / 1$ for progesterone. All analyzes were performed in duplicate, the coefficient of variation in the assay did not exceed $15 \%$.

Twelve months post calving, after analysis of zootechnical data and pedigree records, the reproduction indices (i.e. the proportion of pregnant animals, open days, insemination index) and the yield for 305 days of lactation were determined in both groups.

The data was processed using the one-way ANOVA method and the two-way ANOVA variance analysis with SigmaStat software (Systat Software, Inc., USA). The results are presented as mean values $(X)$ and standard error (SEM). The significance of differences of the mean values compared was assessed using Tukey's test.

Results. Subcutaneous injection to rats of $0.5 \mathrm{ml}$ of the placenta extract for 1 week did not cause an inflammation the site of administration. The general condition of the animals was satisfactory.

Before the introduction of the placenta extract to cows (1-2 weeks before calving), the biochemical blood indices and the content of sex steroid hormones in the compared groups did not differ significantly.

According to the widely accepted opinion, a transit period that covers 2- 
3 weeks to calving and 3 weeks after calving [26] is critically important to determine the health, dairy productivity and reproductive potential of high-yielding cows. This time is characterized by the most pronounced changes in metabolism, which gradually disappear by the end of the first trimester of lactation.
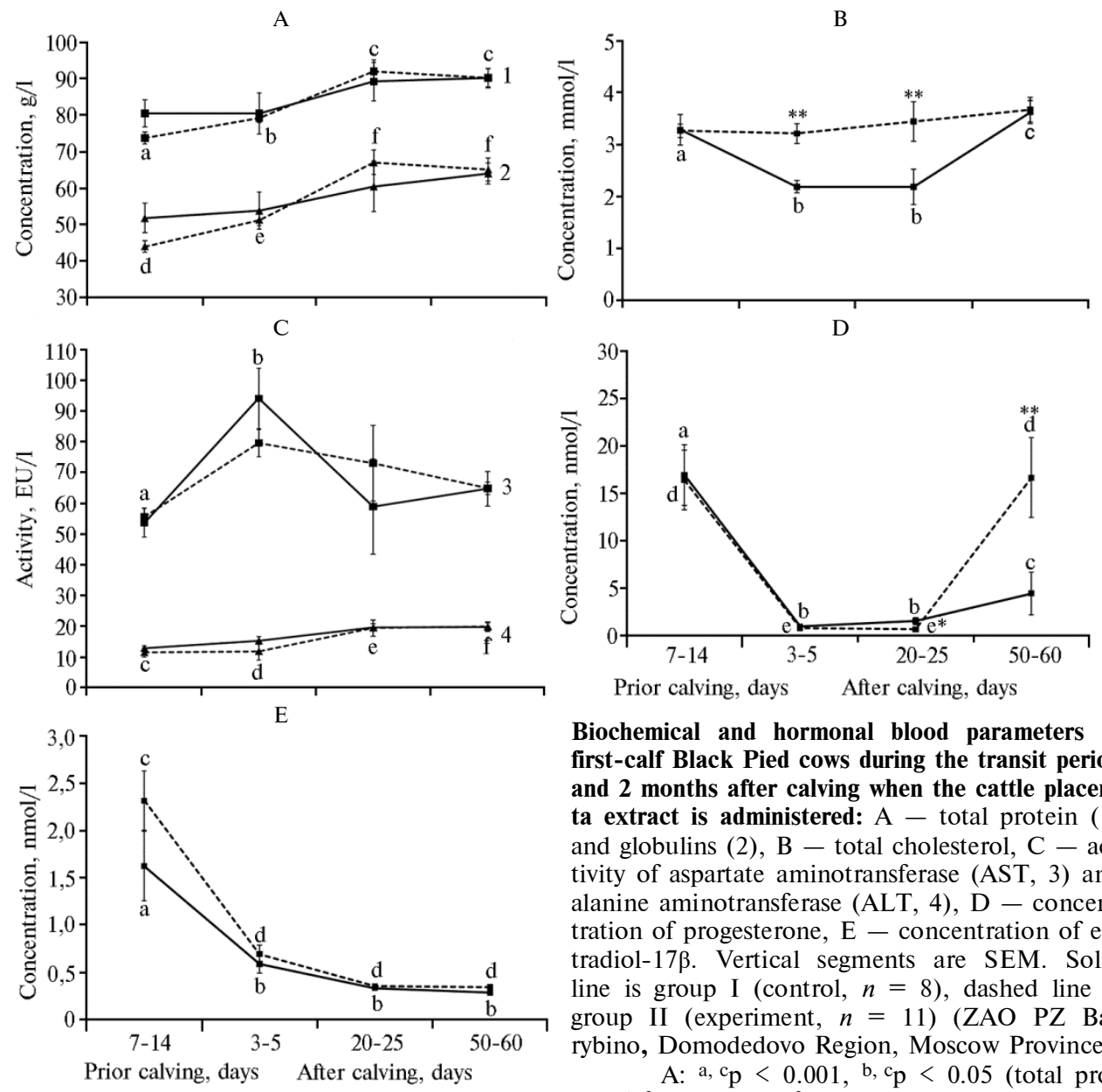

Biochemical and hormonal blood parameters in first-calf Black Pied cows during the transit period and 2 months after calving when the cattle placenta extract is administered: A - total protein (1) and globulins (2), B - total cholesterol, C - activity of aspartate aminotransferase (AST, 3) and alanine aminotransferase (ALT, 4), D - concentration of progesterone, $\mathrm{E}-$ concentration of estradiol-17 $\beta$. Vertical segments are SEM. Solid line is group I (control, $n=8$ ), dashed line is group II (experiment, $n=11$ ) (ZAO PZ Barybino, Domodedovo Region, Moscow Province). A: a, $c_{p}<0.001$, b, $c_{p}<0.05$ (total protein); $\mathrm{d}, \mathrm{f}_{\mathrm{p}}<0.001, \mathrm{e}, \mathrm{f}_{\mathrm{p}}<0.01$ (globulins).

B: ${ }^{a}, b_{p}<0.05, b, c_{p}<0.01$ (total choles-

terol); ${ }^{* *} \mathrm{p}<0.01$ (between the control and experimental groups).

C: ${ }^{a}, b_{p}<0.05$ (АсAT); ${ }^{c}, e_{p}<0.001$, c, $\mathrm{f}_{\mathrm{p}}<0.001$, d, $\mathrm{e}_{\mathrm{p}}<0.01 ;$ d, $\mathrm{f}_{\mathrm{p}}<0.001$ (АлАТ).

D: a, $\mathrm{b}_{\mathrm{p}}<0.001$, a, $\mathrm{c}_{\mathrm{p}}<0.01$, d, $\mathrm{e}_{\mathrm{p}}<0.001$ (progesterone); ${ }^{*} \mathrm{p}<0.05,{ }^{* *} \mathrm{p}<0.01$ (between the control and experimental groups). E: ${ }^{a}, b_{p}<0.001$, c, $\mathrm{d}_{\mathrm{p}}<0.001$ (estradiol-17 $\beta$ ).

Administration of the placenta extract modified a number of biochemical parameters during the transit period. In the group II between 7-14 days to calving and 20-25 days after calving, total proteins significantly $(\mathrm{p}<0.001)$ increased by $24.9 \%$ and globulin fraction increased by $51,8 \%$ which was not observed in the control group (Fig., A).

The blood cholesterol level in control animals decreased by $33 \%(\mathrm{p}<0.05)$ to day 3-5 after calving, persisted to days 20-25, and then increased $(\mathrm{p}<0.01)$ to the pre-calving values to days 50-60 (see Fig., B). In the animals receiving the preparation, the indicator did not change during the whole period of the study. In the middle and at the end of the transit period, the concentration of blood cholesterol in the cows of the experimental group was 1.5-1.6 times higher than that in the control group $(\mathrm{p}<0.01)$.

On days 3-5 after calving, a sharp increase in the activity of AST in the control (by $75.2 \%, \mathrm{p}<0.05$ ) occurred whereas in the experimental group an 
increase was much less pronounced (see Fig., C). The activity of blood ALT in the cows of group II did not change until the middle of the transit period, but increased by $68.8 \%(\mathrm{p}<0.001)$ to its end (see Fig., C). In the control, the ALT activity increased insignificantly and gradually. At the same time, we did not detect the effect of the placenta extract on the concentration of albumins, urea, bilirubin, calcium, phosphorus and on their changes in the postpartum period.

The placenta extract also had a long-term effect on hormonal status. In both groups, the progesterone concentration decreased almost 20-fold on days 3-5 after calving and remained low until the end of the transit period (see Fig., D). At the same time on days 20-25 after calving, this index in animals from group II was $57.7 \%$ lower $(\mathrm{p}<0.05)$ than in control. On days 50-60 after calving, the progesterone level in the experimental cows increased sharply $(26$-fold, $p<0.001)$ which indicated the beginning of luteal activity of the ovaries. In control animals, the progesterone concentration increased less significantly, remaining almost 4 times lower than in group II $(\mathrm{p}<0.01)$. The estradiol-17 $\beta$ concentration and its decrease in first-calf cows in the postpartum period were similar in animals of both groups (see Fig., E).

Reproduction and milk productivity in Black Pied first-calf cows with subcutaneous administration of cattle placenta extract before and during calving $(X \pm \mathrm{SEM}, \mathrm{ZAO}$ PZ Barybino, Domodedovo Region, Moscow Province, 2015-2016 )

\begin{tabular}{l|c|c}
\hline \multirow{2}{*}{ Parameter } & \multicolumn{2}{c}{ Groups } \\
\cline { 2 - 3 } & I, control $(n=8)$ & II $(n=11)$ \\
\hline Percentage of pregnant animals & $75.0 \pm 15.3$ & $90.9 \pm 8.7$ \\
Open days & $123.5 \pm 10.5$ & $95.1 \pm 5.8^{*}$ \\
Insemination index & $1.5 \pm 0.3$ & $1.5 \pm 0.2$ \\
Yield of milk within 305 days of lactation, $\mathrm{kg}$ & $7209 \pm 546$ & $7256 \pm 251$ \\
N o t e. Description of the groups is given in the Technique section. & \\
* Differences between the control and experimental groups are statistically significant at $\mathrm{p}<0.05$. \\
\hline
\end{tabular}

Administration of the placenta extract to animals resulted in a significant reduction in the duration of the open days (by 28.4 days, $\mathrm{p}<0.05$ ), and slightly increased artificial insemination (by $15.9 \%$ ), but did not affect the insemination index (Table). Milk productivity for 305-day lactation in the experimental and control groups was almost the same.

Consequently, the most significant metabolic changes in the first-calf cows caused by cattle placenta extract are associated with lipid metabolism, namely, with maintaining higher concentration of blood cholesterol during the transit period. The cholesterol remained within the limits of normal values for this indicator. A similar tendency towards an increase in cholesterol in the postpartum period was observed in red-and-white multiparous cows after application of extract from human placenta [22]. Previously, it was shown that the blood cholesterol concentration in high-yielding cows in the post-calving period is positively associated with the restoration of sexual circularity and a decrease in open days [27, 28]. These data are consistent with the results obtained by us.

It is known that the mobilization of fat depots in early lactation leads to an increase in the blood concentration of free fatty acids, and the $\beta$-oxidation of these fatty acids leads to an excess of acetyl-CoA and an increase in the synthesis of ketone bodies in the liver [7, 8]. Ketone bodies, in turn, adversely influence the reproductive function in cows [29]. Therefore, a positive relationship between the cholesterol concentration and the reproductive ability of cows may be due to a partial use of excess acetyl-CoA for cholesterol production and a corresponding decrease in the synthesis of ketone bodies. Besides, cholesterol is able to reduce the rate of metabolic clearance of progesterone necessary for adequate maintenance of pregnancy [6,30].

Thus, the administration of cattle placenta extract before and during 
calving has a modulating effect on metabolic processes (primarily lipid metabolism) in the first-calves in the postpartum period. The extract also causes an increase in the luteal activity of the ovaries 2 months after calving which indicates stimulation of the animals' transition from the state of postpartum anestrus. Normalization of the metabolic and hormonal status of cows is obviously associated with an increase in the reproductive ability of animals and reduces open days.

\section{R E F E R E N C E S}

1. Chag as L.M., B a s s J.J., B 1 a che D., B u rke C.R., K a y J.K., Lind s a D.R., Lu cy M.C., Martin G.B., Meier S., Rhodes F.M., Roche J.R., Thatcher W.W., $\mathrm{W}$ e b b R. Invited review: New perspectives on the roles of nutrition and metabolic priorities in the subfertility of high-producing dairy cows. J. Dairy Sci., 2007, 90(9): 4022-4032 (doi: $10.3168 /$ jds.2006-852).

2. Ly a g i n F.F. Zootekhniya, 2003, 5: 25-27. Available http://elibrary.ru/item.asp?id=9125091. No date.

3. Dobs o n H., S mith R.F., Royal M.D., Knight Ch., Sheldon I. The high producing dairy cow and its reproductive performance. Reprod. Domest. Anim., 2007, 42(2): 17-23 (doi: 10.1111/j.1439-0531.2007.00906.x).

4. B r i c k e 11 J.S., Wat he s D.C. A descriptive study of the survival of Holstein-Friesian heifers through to third calving on English dairy farms. J. Dairy Sci., 2011, 94(4): 1831-1838 (doi: 10.3168/JDS.2010-3710).

5. W u J.J., Wathes D.C., B ri cke 11 J.S., Y a ng L.G., C he ng Z., Z h a o H.Q., $\mathrm{Xu}$ Y.J., $\mathrm{Zh} \mathrm{ang}$ S.J. Reproductive performances and survival of Chinese Holstein dairy cows in central China. Anim. Prod. Sci., 2012, 52(1): 11-19 (doi: 10.1071/AN11146).

6. W at h e s D.C. Mechanisms linking metabolic status and disease with reproductive outcome in the dairy cow. Reprod. Domest. Anim., 2012, 47(4): 304-312 (doi: 10.1111/j.1439-0531.2012.02090.x).

7. Wat hes D.C., Cle m p s on A.M., P ollott G.E. Associations between lipid metabolism and fertility in the dairy cow. Reprod. Fertil. Dev., 2012, 25: 48-61 (doi: 10.1071/RD12272).

8. Van Knegsel A.T.M., van den Brand H., Dijkstra J., Tamminga S., $\mathrm{Ke} \mathrm{m} \mathrm{p} \mathrm{B.} \mathrm{Effect} \mathrm{of} \mathrm{dietary} \mathrm{energy} \mathrm{source} \mathrm{on} \mathrm{energy} \mathrm{balance,} \mathrm{production,} \mathrm{metabolic} \mathrm{disorders}$ and reproduction in lactating dairy cattle. Reprod. Nutr. Dev., 2005, 45(6): 665-688 (doi: 10.1051/rnd:2005059).

9. Lebedev V.A., Le be deva I.Yu., Kuz'mina T.I., Shapiev I.Sh. Role of metabolic hormones in the regulation of ovarian function in cattle (review). Agricultural Biology, 2005, 2: 14-22 (in Russ.).

10. Et te m a J.F., S a n t o s J.E. Impact of age at calving on lactation, reproduction, health, and income in first-parity Holsteins on commercial farms. J. Dairy Sci., 2004, 87: 2730-2742 (doi: 10.3168/jds.S0022-0302(04)73400-1).

11. Xu Z.Z., Burton L.J., McDougall S., Jolly P.D. Treatment of noncyclic lactating dairy cows with progesterone and estradiol or with progesterone, GnRH, prostaglandin F2 alpha, and estradiol. J. Dairy Sci., 2000, 83(3): 464-470 (doi: 10.3168/jds.S0022-0302(00)74904-6).

12. Bhoraniya H.L., D ha mi A.J., Naik o o M., P a r ma r B.C., S a rvai y a N.P. Effect of estrus synchronization protocols on plasma progesterone profile and fertility in postpartum anestrous Kankrej cows. Trop. Anim. Health Prod., 2012, 44(6): 1191-1197 (doi: 10.1007/s11250-011-0057-1).

13. $\mathrm{Pal}$ ' $\mathrm{c} \mathrm{h}$ i k ov M.Yu. Bionormalizuyushchee deistvie preparatov iz platsenty cheloveka pri rannei stimulyatsii polovoi tsiklichnosti $u$ korov. Kandidatskaya dissertatsiya [Bionormalizing effect of human placenta extract for early stimulation of ovarial cycle in cows. PhD Thesis]. Belgorod, 2005 (in Russ.).

14. G i z a t u $11 \mathrm{i} \mathrm{n} \mathrm{P.P.} \mathrm{Gigienicheskoe} \mathrm{obosnovanie} \mathrm{korrektsii} \mathrm{estestvennoi} \mathrm{rezistentnosti} \mathrm{organizma}$ telyat biologicheskim stimulyatorom «Biostim». Kandidatskaya dissertatsiya [Hygienic evidence for correction of natural resistance in calves by Biostim, the biostimulating preparation. PhD Thesis]. Ufa, 2001 (in Russ.).

15. Lo bo di n K.A., N e zh da nov A.G., B u z l a m a V.S. Veterinariya, 2006, 3: 39-44. Available http://elibrary.ru/item.asp?id=9242703. No date (in Russ.).

16. B l a n k M.S., Fri e s e n H.G. Effects of placentophagy on serum prolactin and progesterone concentrations in rats after parturition or superovulation. J. Reprod. Fertil., 1980, 60(2): 273-278 (doi: 10.1530/jrf.0.0600273).

17. Wu C.H., Chang G.Y., Chang W.C., Hsu C.T., Che n R.S. Wound healing effects of porcine placental extracts on rats with thermal injury. Br. J. Dermatol., 2003, 148(2): 236-245 (doi: 10.1046/j.1365-2133.2003.05164.x).

18. H o ng J.W., L e e W.J., H a h n S.B., K i m B.J., L e w D.H. The effect of human placenta extract in a wound healing model. Ann. Plast. Surg., 2010, 65(1): 96-100 (doi: 10.1097/SAP.0b013e3181b0bb67).

19. Park S.Y., Phark S., Le e M., Li m J.Y., S u 1 D. Anti-oxidative and anti inflammatory activities of placental extracts in benzo[a] pyrene-exposed rats. Placenta, 2010, 31(10): 873-879 (doi: 10.1016/j.placenta.2010.07.010). 
20. Mity a s hova O.S. V sbornike: Biologiya - nauka XXI veka. [In: Biology - the science of XXI century]. Pushchino, 2015: 353-354. Available http://www.psn.ru/biology21/Page354.pdf. No date (in Russ.).

21. Cotor G., Pop A., Ghit a M. The effect of ovine placenta extract on mammogenesis, lactogenesis, and galactopoiesis in sheep. Turk. J. Vet. Anim. Sci., 2011, 35: 137-142.

22. L o b o d i n K.A. Veterinariya, 2006, 7: 38-42. Available http://elibrary.ru/item.asp?id=9242726. No date (in Russ.).

23. Kornienko V.S. Lekarstvennyi preparat ban. A.C. 2140275 (RF) MKI3 A61K35/12, A61K35/50. Filial N 5 GNTS-Institut biofiziki FU «Medbioekstrem» pri MZ Rossii. № 98110825/13 [Ban, the medicinal preparation. A.C. 2140275 (RF) MKI3 A61K35/12, A61K35/50. Subsidiary N 5, GNC-Institute of Biophysics of Medbioextrem, Ministry of Health of the Russian Federation № 98110825/13]. Appl. June 04, 1998. Publ. October 27, 1999 (in Russ.).

24. Varenikov M.V., Chomaev A.M., Artyukh V.M., Prytkov Yu.A., Lie pa V.L. Sposob polucheniya biostimulyatora iz platsenty korov. A.S. 2377999 (RF) MKI3 A61K35/50. Vserossiiskii gosudarstvennyi nauchno-issledovatel'skii institut zhivotnovodstva (VIZH). №2007143944/13 [Method for preparation of a biostimulating biological from cow placenta. A.C. 2377999 (RF) MKIZ A61K35/50. All-Russian State Institute of Animal Husbandry (VIZh). № 2007143944/13]. Appl. November 29, 2007. Publ. January 10, 2010 (in Russ.).

25. L i e $\mathrm{p}$ a V.L. Vliyanie primeneniya Platsentina- $A v$ sochetanii s biologicheski aktivnymi veshchestvami na sroki involyutsii matki u korov. Avtoreferat kandidatskoi dissertatsii [A combined influence of Placentin-A and bioactive compounds on timing of uterus involution in cows. PhD Thesis]. Dubrovitsy, 2011 (in Russ.).

26. Zebeli Q., Ghareeb K., Humer E., Metzler-Zebeli B.U., Besenfelder U. Nutrition, rumen health and inflammation in the transition period and their role on overall health and fertility in dairy cows. Res. Vet. Sci., 2015, 103: 126-136 (doi: 10.1016/j.rvsc.2015.09.020).

27. Dhami A.J., $\mathrm{Nakrani}$ B.B., Hadiya K.K., P a t e 1 J.A., $\mathrm{S} h$ a h R.G. Comparative efficacy of different estrus synchronization protocols on estrus induction response, fertility and plasma progesterone and biochemical profile in crossbred anestrus cows. Vet. World, 2015, 8(11): 1310-1316 (doi: 10.14202/vetworld.2015.1310-1316).

28. Reist M., Erdin D.K., von Euw D., Tschümperlin K.M., Leuenberger H., Ham mon H.M., Morel C., Philipona C., Zbinden Y., Künzi N., Blum J.W. Postpartum reproductive function: association with energy, metabolic and endocrine status in high yielding dairy cows. Theriogenology, 2003, 59(8): 1707-1723 (doi: 10.1016/S0093-691X(02)01238-4).

29. Shin E.K., J e ong J.K., Choi I.S., Kang H.G., H u r T.Y., Jung Y.H., Kim I.H. Relationships among ketosis, serum metabolites, body condition, and reproductive outcomes in dairy cows. Theriogenology, 2015, 84: 252-260 (doi: 10.1016/j.theriogenology.2015.03.014).

30. Haw ki ns D.E., N is w e nd e r K.D., O s s G.M., M o e 11 e r C.L., O d d e K.G., S a w y e $r$ H.R., $\mathrm{N}$ is w e $\mathrm{nde} r$ G.D. An increase in serum lipids increases luteal lipid content and alters the disappearance rate of progesterone in cows. J. Anim. Sci., 1995, 73(2): 541-545 (doi: $10.2527 / 1995.732541 x)$. 